\title{
PENDAMPINGAN PENYUSUNAN DED PEMBANGUNAN PUSKESMAS KECAMATAN DEMPO UTARA KOTA PAGAR ALAM
}

\author{
Alharia Dinata \\ Program Studi Teknik Sipil; Sekolah Tinggi Teknologi Pagaralam (STTP) \\ Jl. M. Siagim No. 75. Karang Dalo, Dempo Tengah, Kota Pagar Alam \\ Telp/Fax: (0730) 621916 \\ e-mail: Alhariadinata@yahoo.co.id
}

\begin{abstract}
Abstrak
Puskesmas merupakan organisasi fungsional penyelenggara upaya kesehatan bersifat menyeluruh, terpadu, merata dapat diterima dan terjangkau masyarakat dengan peran serta aktif masyarakat dan menggunakan hasil pengembangan ilmu pengetahuan dan teknologi tepat guna, dengan biaya yang dapat dipikul oleh pemerintah dan masyarakat luas guna mencapai derajat kesehatan yang optimal, tanpa mengabaikan mutu pelayanan kepada perorangan (Depkes, 2009). Sesuai dengan keadaan geografi, luas wilayah, sarana perhubungan, dan kepadatan penduduk dalam wilayah kerja Puskesmas. Agar jangkauan pelayanan Puskesmas lebih merata dan meluas, Puskesmas perlu ditunjang dengan Puskesmas pembantu, penempatan bidan di desa yang belum terjangkau oleh pelayanan yang ada, dan Puskesmas keliling. Disamping itu pergerakkan peran serta masyarakat untuk mengelola posyandu. Dalam penataan ruang kawasan, memuat perencanaan dan pemanfaatan potensi yang ada. sehingga dapat memberikan arah untuk pengembangan di segala bidang pembangunan yang bersifat meluas dan tidak dominan pada konsentrasi daerah tertentu saja. Dengan ini sebelum adanya pembangunan puskesmas maka dibutuhkan adanya DED, sebagai arahan pembangunan.
\end{abstract}

Kata kunci-Puskesma, Pengetahuan, Bidan, Posyandu, Pembangunan, DED.

\section{PENDAHULUAN}

Pusat Kesehatan Masyarakat (Puskesmas) adalah salah satu sarana pelayanan kesehatan masyarakat yang amat penting di Indonesia. Puskesmas adalah unit pelaksana teknis dinas kabupaten/kota yang bertanggungjawab menyelenggarakan pembangunan kesehatan di suatau wilayah kerja (Depkes, 2011). Pengertian puskesmas adalah suatu unit pelaksana fungsional yang berfungsi sebagai pusat pembangunan kesehatan, pusat pembinaan peran serta masyarakat dalam bidang kesehatan serta pusat pelayanan kesehatan tingkat pertama yang menyelenggarakan kegiatannya secara menyeluruh, terpadu yang berkesinambungan pada suatu masyarakat yang bertempat tinggal dalarn suatu wilayah tertentu (Azrul Azwar, 1996).

Jika ditinjau dari sistim pelayanan kesehatan di Indonesia, maka peranan dan kedudukan puskesmas adalah sebagai ujung tombak sistem pelayanan kesehatan di Indonesia. Sebagai sarana pelayanan kesehatan terdepan di Indonesia, maka Puskesmas bertanggungjawab dalam menyelenggarakan pelayanan kesehatan masyarakat, juga bertanggung jawab dalatn menyelenggarakan pelayanan kedokteran.

Sesuai dengan kemampuan tenaga maupun fasilitas yang berbeda-beda, maka kegiatan pokok yang dapat dilaksanakan sebuah puskesmas akan berbeda pula. Namun demikian kegiatan pokok Puskesmas yang seharusnya dilaksanakan adalah sebagai berikut : KIA, Keluarga Berencana, Usaha Perbaikan Gizi, Kesehatan Lingkungan, Pencegahan dan Pemberantasan Penyakit Menular, Pengobatan termasuk pelayanan darurat karena kecelakaan, penyuluhan Kesehatan Masyarakat, Kesehatan Sekolah, Kesehatan Olah Raga, Perawatan Kesehatan Masyarakat, Kesehatan dan keselamatan Kerja, Kesehatan Gigi dan Mulut, Kesehatan Jiwa, 
Kesehatan Mata, Laboratorium Sederhana, Pencatatan Laporan dalam rangka Sistem Informasi Kesehatan, Kesehatan Usia Lanjut dan Pembinaan Pengohatan Tradisional.

\section{METODE}

Teknik yang digunakan dalam penyampaian materi pendampingan adalah workshop, dengan menggunakan alat bantu berupa laptop, LCD.

\subsection{Materi}

1. Persiapan

a. Persiapan awal pelaksanaan

b. Mempersiapkan sumber daya yang diperlukan untuk dapat melakukan pekerjaan. Memperoleh gambaran lengkap pekerjaan dengan menggali berbagai masukan dan harapan dari pemilik pekerjaan secara mendalam.

2. Pengumpulan data dan informasi lapangan (data primer), dan data pendukung lainnya berupa:

a. Melakukan pengumpulan data kependudukan.

b. Melakukan pengumpulan data kesehatan di Instansi terkait.

c. Melakukan Survey Lokasi fasilitas kesehatan yang sudah ada.

d. Melakukan Survey Lokasi.

3. Tahap Penelitian (Pengolahan dan Analisis Data)

Penelitian terhadap data - data yang ada dilakukan secara mendalam dengan menggunakan metode ilmiah, sampai dengan menyimpulkan dan menyajikan hasil penelitian.Pada tahap ini dapat dilihat profil yang paling tepat sesuai dengan segment, target, positioning serta strategi.

4. Tahap Evaluasi Proyek Bisnis.

Pada tahap ini melakukan kajian kelayakan secara bisnis atas segala upaya yang akan dikeluarkan dibandingkan dengan hasil yang akan didapat.

5. Tahap Rekomendasi

Merekomendasikan kelayakan rencana pembangunan berdasarkan kesimpulan dari seluruh hasil kajian kelayakan dengan menggunakan parameter kelayakan sesuai dengan ketentuan yang berlaku. Ruang Lingkup Kegiatan Rencana Induk/ Master Plan dan DED (Detail Engineering Design)

a. Tahap persiapan

Mempersiapkan berbagai metodologi, konsep, kebijakan, standar dan pedoman yang akan menjadi pegangan dalam perancangan puskesmas

b. Tahap pengumpulan data dan informasi lapangan. Pengumpulan data dan informasi di lapangan baik itu demografi, infrastruktur, lokasi site engineering, dan lainya.

c. Tahap pengukuran topografi (1:1000) Pengukuran lokasi yang telah ditetapkan berdasarkan kajian FS (Feasibility Study) dengan menggunakan peralatan total station atau RTK untuk mendapatkan peta topografi (eksisting location), kontur, bangunan yang ada, aksesibilitas/jalan, sungai, dan lainnya sesuai hasil pengukuran di lapangan.

d. Tahap pra rancangan

Perancangan awal puskesmas berupa konsep rancangan berdasarkan standar minimum pelayanan, jenis bangunan, letak bangunan, tema bangunan, ruang terbuka hijau, perparkiran, dan lain-lain sesuai kebutuhan.

e. Tahap rancangan

Rancangan yang telah mendapat persetujuan dari pemberi pekerjaan dan telah dipresentasikan di daerah, serta telah melalui proses konsultasi.

\section{Proses Penyusunan DED (Detail Engineering Design)}

1. Gambar rancangan detail bangunan/bestek. Lengkap dengan gambar rencana teknis arsitektur, struktur, mekanikal dan elektrikal serta tata lingkungan. 
2. Engineer estimate: Rencana anggaran biaya berupa perhitungan volume masing-masing satuan pekerjaan, yang dibuat berdasarkan gambar dan menjadi HPS (Harga Perhitungan Sendiri).

3. Daftar volume pekerjaan atau disebut (bill of quantity)

4. Rencana Kerja dan Syarat-Syarat. Mencakup persyaratan mutu dan kuantitas material bangunan, dimensi material bangunan, prosedur pemasangan material dan persyaratanpersyaratan lain yang harus dipenuhi oleh pelaksana konstruksi. RKS menjadi syarat yang harus dipenuhi penyedia dan dimasukkan ke dalam dokumen pengadaan.

\section{Laporan Final (DED)}

Berupa laporan akhir setiap tahapan perencanaan yang meliputi;

1. Laporan Arsitektur;

2. Laporan perhitungan struktur termasuk laporan penyelidikan tanah (soiltest);

3. Laporan perhitungan mekanikal dan elektrikal;

4. Laporan tata lingkungan.

\subsection{Perumusan Masalah}

Sesuai dengan amanat undang-undang dasar Republik Indonesia 1945 bahwa pelayanan kesehatan merupakan hak dasar setiap orang yang dijamin dan harus diwujudkan dengan upaya peningkatan derajat kesehatan masyarakat yang setingi-tingginya. Dan Puskesmas adalah sarana yang menjadi salah satu sarana untuk membantu masyarakat dalam mewujudkan peningkatan kesehatan. Puskesmas adalah institusi pelayanan kesehatan bagi masyarakat dengan karateristik tersendiri yang dipengaruhi oleh perkembangan ilmu pengetahuan kesehatan, kemajuan teknologi, dan kehidupan sosial ekonomi masyarakat yang harus tetap mampu meningkatkan pelayanan yang lebih bermutu dan terjangkau masyarakat agar terwujud derajat kesehatan yang setinggi-tingginya. Adanya pedoman pembangunan puskesmas bagi Kec. Dempo Utara sesuai dengan dinamika perubahan dan perkembangan dimasa mendatang, serta mendapat kesesuaian fisik dan tidak terjadi fenomena tambal sulam di masa mendatang maka dibutuhkan adanya $D E D$.

\section{HASIL DAN PEMBAHASAN}

Maka dari proses pengabdian yang dilakukan oleh pelaksana pengabdian maka berikut hasil dan pembahasannya, berdasarkan metode atau cara yang dilakukan:

\subsection{Hasil}

Pelaksanaan pendampingan penyusunan DED puskesmas Kec. Dempo Utara dilakukan untuk mendukung pembangunan fasilitas kesehatan di Kec. Dempo Utara Kota Pagar Alam. Puskesmas merupakan memberi pelayanan kesehatan langsung kepada masyarakat.Bekerjasama dengan sektor-sektor yang bersangkutan dalam melaksanakan program puskesmas.

\subsection{Pembahasan}

Puskesmas adalah salah satu unit pelaksana pembangunan kesehatan Pagar Alam dan merupakan bagian integral dari pembangunan nasional, oleh karena itu kesehatan adalah suatu aspek yang mempengaruhi kualits dan produktifitas sumber daya manusia dalam rangka mewujudkan masyarakat yang makmur dan sejahtera. Kesehatan yang ingin dicapai adalah keadaan kesejahteraan dalam dari badan, jiwa,dan sosial yang memungkinkan setiap orang hidup produktif secara sosial dan ekonomis. Tujuan ini hanya dapat diwujudkan oleh petugas kesehatan dan peran serta masyarakat.

Kesehatan merupakan salah satu investasi termahal dalam hidup dan juga merupakan suatu anugerah dari Tuhan yang tak ternilai harganya. Sebanyak apapun harta yang dimiliki oleh seseorang tentu tidak akan ada artinya apa bila orang tersebut tidak mempunyai tubuh yang sehat. Menjaga kesehatan itu perlu agar tubuh selalu sehat jasmani dan rohani akan tetapi tidak selamanya seseorang tersebut selalu berada dalam keadaan sehat, ada kalanya seseorang harus terjatuh sakit. Berbagai cara dilakukan agar seseorang dapat kembali menjadi sehat salah satu cara 
yang dilakukan masyarakat pada umumnya adalah dengan memeriksakan diri ke tempat-tempat pelayanan kesehatan seperti puskesmas.

Puskesmas adalah suatu kesatuan organisasi kesehatan fungsional yang merupakan pusat pengembangan kesehatan masyarakat, membina peran serta masyarakat, memberikan pelayanan secara menyeluruh dan terpadu kepada masyarakat di wilayah kerjanya dalam bentuk kegiatan pokok. Oleh karena itu puskesmas mempunyai wewenang dan tanggung jawab atas pemeliharaan kesehatan masyarakat dalam wilayah kerjanya. Puskesmas tersebar hampir di berbagai daerah biasanya selalu ada di tiap kecamatan dengan jangkauan luas daerah operasional yang sesuai.

Puskesmas menyelenggarakan upaya yang bersifat menyeluruh, terpadu, merata dapat di terima dan terjangkau oleh masyarakat, dengan peran serta aktif masyarakat dan menggunakan hasil pengembangan ilmu pengetahuan dan teknologi tepat guna, dengan biaya yang dapat di pikul oleh pemerintah dan masyarakat. Lingkup perencanaan lingkungan, site/tapak bangunan, dan perencanaan fisik bangunan gedung negara yang terdiri dari:

a. Persiapan Perencanaan seperti mengumpulkan data dan informasi lapangan, membuat interpretasi secara garis besar terhadap KAK, dan konsultasi dengan pemerintah daerah setempat mengenai peraturan daerah/perijinan bangunan.

b. Menyusun Pra Rencana seperti rencana lay-out, pra rencana bangunan termasuk program dan konsep ruang, perkiraan biaya.

c. Penyusunan pengembangan rencana, antara lain membuat :

1. Rencana arsitektur/ Interior, dan uraian konsep yang mudah dimengerti pemberi tugas

2. Rencana struktur, beserta uraian konsep dan perhitungannya.

3. Rencana utilitas, beserta uraian konsep dan perhitungannya.

4. Perkiraan biaya.

d. Penyusunan rencana detail antara lain membuat :

1. Gambar - gambar detail arsitektur/ Interior, detail struktur, detail utilitas yang sesuai dengan gambar rencana yang telah disetujui.

2. Rencana Kerja dan syarat - syarat (RKS).

3. Rincian volume pelaksanaan pekerjaan, rencana anggaran biaya pekerjaan.

\section{KESIMPULAN}

Dengan adanya instalasi kesehatan seperti puskesmas sangat membantu menjaga kesehatan masyarakat, tetapi sejalan dengan perubahan puskesmas harus mampu mengelola alat kesehatan, obat - obatan dengan baik. Kesehatan yang ingin dicapai adalah keadaan kesejahteraan dari badan jiwa dan sosial orang memungkinkan setiap orang hidup produktif secara sosial dan ekonomi. Sebagaimana juga dinyatakan dalam GBHN dan sistem kesehatan nasional bahwa tujuan pembangunan dalam bidang yang optimal sebagai salah satu unsur kesejahteraan umum. Untuk mencapaitujuan ini diperlukan sistem kesehatan nasional sebagai pemikiran dasar yang memberi arah tujuan, bentuk dan sifat pembangunan kesehatan yang dilaksanakan nantinya dapat bersifat menyeluruh, terpadu dan berkesinambungan. Berdasarkan sistem pelayanan kesehatan yang terdapat di Indonesia,maka Puskesmas mencapai bagian terdepan dalam memberi pelayanan kesehatan pada masyarakat..

\section{SARAN}

Untuk mencapai visi pembangunan kesehatan melalui puskesmas yakni terwujudnya kecamatan sehat menuju indonesia sehat, puskesmas bertanggung jawab menyelenggarakan upaya kesehatan perorangan (UKP) dan upaya kesehatan masyarakat (UKM) yang keduanya jika di tinjau dari sistem kesehatan nasional merupakan pelayanankesehatan tingkat pertama. Upaya kesehatan wajib puskesmas adalah upaya yang di tetapkan berdasarkan komitmen nasional, regional dan global serta yang mempunyai daya ungkit tinggi untuk meningkatkan derajat kesehatan masyarakat. Upaya kesehatan wajib ini harus diselenggarakan oleh setiap Puskesmas yang ada di wilayah Indonesia.

\section{UCAPAN TERIMA KASIH}


Penulis mengucapkan terima kasih seluruh peserta pengabdian dan kuliah kerja nyata (KKN) Sekolah Tinggi Teknologi Pagaralam, Terima Kasih Kepada LPPM divisi Pengabdian Kepada Masyarakat.

\section{DAFTAR PUSTAKA}

[1] Muslim, B. 2018. Pelatihan aplikasi editing video dengan filmora., Laporan Pengabdian Kepada Masyarakat, LPPM STT Pagaralam.

[2] Azrul Azwar. 1996. Pengantar Administrasi Kesehatan. Edisi Ketiga. Jakarta : Binarupa. Aksara.

[3] Departmen Kesehatan. 2009. Sistem Kesehatan. Jakarta.

[4] Departmen Kesehatan. 2007. Direktorat Jendral Bina pelayanan Medik Standar Minimal Pelayanan Kesehatan Gigi Puskesmas.

[5] Isro'Mukti, Y. (2017). Sistem Informasi Madrasah Aliyah Negeri Pagar Alam Berbasis Web. Indonesian Journal of Computer Science, 6(2), 192-205.

[6] Mukti, Y. (2017). Perencanaan Strategis Sistem Informasi Dan Teknologi Informasi Pada Sekolah Menengah Kejuruan Negeri 2 Pagar Alam. JURNAL ILMIAH BETRIK: Besemah Teknologi Informasi dan Komputer, 8(02), 83-92.

[7] Arif, A., \& Mukti, Y. (2017). Rancang Bangun Website Sekolah Menengah Pertama (SMP) Negeri 8 Kota Pagar Alam. JURNAL ILMIAH BETRIK: Besemah Teknologi Informasi dan Komputer, 8(03), 156-165.

[8] Isro'Mukti, Y. (2018, October). Sistem Informasi Manajemen Aset Sekolah Tinggi Teknologi Pagaralam Berbasis Web. In Seminar Nasional Teknologi Informasi dan Komunikasi (SEMNASTIK) (Vol. 1, No. 1, pp. 632-638).

[9] Mukti, Y. (2018). Rancang Bangun Website Sekolah Dengan Metode User Centered Design (UCD). JURNAL ILMIAH BETRIK: Besemah Teknologi Informasi dan Komputer, 9(02), 84-95. 